\section{East Germany may debate pollution}

LAST week, the Mecklenberg Synod of the Evangelical Lutheran Church issued a call for public discussion on the dangers of nuclear energy - the first time that the issue has been raised in the GDR. The church in East Germany is not often outspoken on matters outside its immediate concern, and the Mecklenberg proposal for talks between politicians, scientists and churchmen on the nuclear issue is unlikely to receive unqualified official approval.

Judging from the listed "priorities" for science and technology in the current five year plan, environmental issues are not a prime concern of the East German planners, except perhaps as regards water resources which are extremely scanty $\left(2,100 \mathrm{~m}^{3} /\right.$ year per head of the population, according to 1970 Comecon figures, as against the Soviet Union with 19,600 $\mathrm{m}^{3} /$ year, Bulgaria with $24,000 \mathrm{~m}^{3} /$ year, and Hungary $\left(12,000 \mathrm{~m}^{3} /\right.$ year per head).

Conservation, to the East German planners, seems primarily to mean energy saving - as exemplified in last week's address of State Secretary Ziergiebel to the "Urania" society for the dissemination of scientific knowledge. The future problems of the energy industry are enormous and are by no means easy to solve, he said. Energy saving, in the present world situation, is "a principle of socialist economic management", which, by the use of effective technologies, can effect, as in the case of the Leuna combine, "a millionfold saving".

The Magdeburg appeal, however, seems

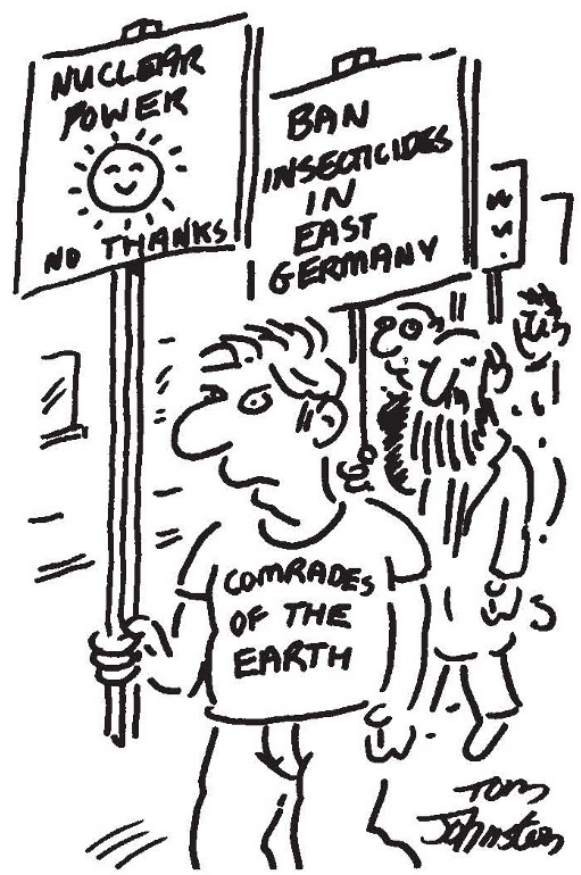

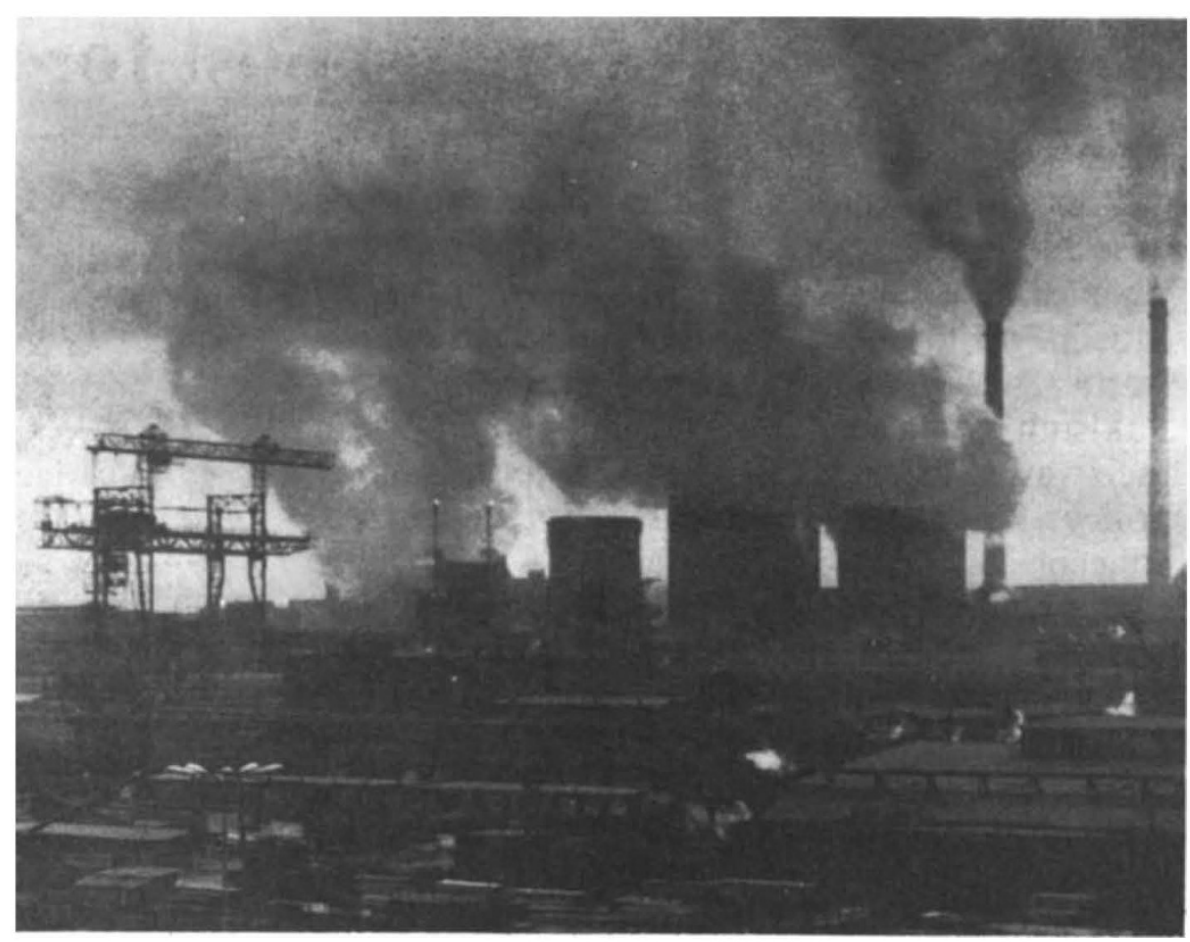

'Walter Ubricht' chemical plant, Halle, East Germany: effluents as well as profits

to reflect a wider concern with environmental issues among the East German public at large. The GDR is a notoriously difficult country in which to gauge public opinion - unauthorized communication of information to foreign jouınalists can merit a 12-year jail sentence. However, a recent "exchange of letters" in the prestigious philosophical journal Sinn und Form may well serve as a pointer.

In the first of the letters, Gunter Kunert, a well-known writer, addresses the editor on the dangers inherent in modern technology. He ironically dismisses the "class-standpoint" that science and technology in the hands of "progressive forces" never have the same negative consequences as occur under capitalism". To take but one example, in "industrialized agriculture", "we have a metaphorical tiger by the tail", yet, in spite of the risk of poisoning, "agriculture will get nowhere without insecticides and pesticides", and to abandon them would result in world famine. Quickly he runs through a "catalogue" of possible disasters more familiar to a western than East German readership: the possibility of climatic change through $\mathrm{CO}_{2}$ buildup and the ensuing melting of the polar ice-caps, destruction of the ozone layer by aerosol propellants, the hazards of nuclear energy - in the GDR, he said, all these dangers inherent in the development of civilization are put out of mind. DDT is banned, but new substances, whose effects are only vaguely known, are spread on the fields. No one is concerned with long-term hazards, and people simply proceed on the principle that "the human race will survive - it always has so far!"
Kunert's letter is a moderate and reasoned appeal, not for the abandoning of technological advance, but simply to a greater awareness of long-term and cumulative effects. His stance on pesticides, for example, seems very similar to the attitude of Hungary's plant protection officers. To Wilhelm Girnus, Editor of Sinn und Form, however, Kunert's proposals seem tainted with western doomwatch. Girnus does not, of course, dismiss environmentalism altogether; in his reply, more than three times the length of the original letter, Girnus mentions, though with some doubt, work done on the smoke-pollution of pinetrees, and even waxes enthusiastic over the Soviet Union's integrated plans (which include conservation) for the region to be spanned by the new "Baikal-AmurMainline",

However, his major task is dialectic. From an argument which ranges from the content of socialism to the views of a "certain Herr Schicklgruber" on the vocabulary of "Jewish liberalism", the message emerges; a doomwatch mentality, always on the lookout for "black possibilities" can lead only to "manic sweeping judgements", helplessness, and moral paralysis. In the capitalist world, he says, "a kind of addiction to catastrophic experiences" is becoming rampant. While politely agreeing with Kunert that the "warnings of a serious scientist about the dangers of a new discovery must be taken seriously", in his capacity as editor of a 'eading philosophical journal, Girnus makes the official standpoint abundantly clear. If citizens of the GDR do want to discuss ecology, they must eschew the doomwatch edition.

Vera Rich 